\title{
AGE ANALYSIS OF ALPINE SKI MEDAL WINNERS IN THE 2015-2018 OLYMPIC CYCLE
}

\author{
Zvezdan Savić ${ }^{1}$, Miloš Tomić ${ }^{2}$, Nikola Stojanović ${ }^{1}$ and Đorđe Savić ${ }^{3}$ \\ 1Faculty of Sport and Physical Education, University of Niš, Niš, Serbia \\ ${ }^{2}$ Ski Association of Serbia, Belgrade, Serbia \\ ${ }^{3}$ Faculty of Sport and Physical Education, University of Belgrade, Belgrade, Serbia
}

UDK 796.032.2.926"2015/2018"

\section{SUMMARY}

Motivation, curiosity, as well as engagement and work in skiing led the authors to present the results of such analysis to the readers and the professional public, which could be important for practice. The paper analyzes the average age of professional alpine skiers who won medals at the World Cups, World Championships and Olympic Games in the 2015-2018 Olympic cycle, ie. from the $2014 / 2015$ to $2017 / 2018$ season. The following alpine events were analyzed: Slalom (SL), Giant Slalom (GS), Super G (SG), Downhill (DH) and Alpine Combined (AC). The aim of this paper was viewed through the causal relationships average age of athlete on the podium by seasons and events in which they performed. The basic descriptive statistics were applied, which, based on the calculated arithmetic mean and medians, indicated the average higher age of athletes in speed events (SG and DH) compared to technical ones (SL, GS), as well as the fact that the athletes' skiing career was prolonged. The age of athletes in the $2017 / 2018$ is higher than in the 2014/2015 season for speed (DH, SG, AC) and 2016/2017 than 2014/2015 for tech (SL, GS).

Key words:skiers, age, competitions, analysis, Olympic cycle. 


\section{INTRODUCTION}

Now days skiing belongs in group of the most popular outdoor sports that we go in for different motives (fun, leisure, competition, work). Science and technology are definitely involved in this sport specially in fields of mechanics and aerodynamics, training planning, designing of ski equipment and materials used to produce it. We certainly agree that skiing is actually intersection of fall line with skis, by performing left and right turn, as well as skiing is sport of speed (Savić, Stijepović, 2019). Sports experts work in skiing with different age categories of athletes in different environment. That is a very hard work, complex and responsible but it provides a great pleasure as well (Živanović, Savić, Milojević, Milutinović, 2003). Modern competitive skiing, like most other sports, requires a high degree of specialization for certain competitive disciplines (Matković, Ferenčak, Žvan, 2004). Top competitive results in alpine skiing today largely depend on a good plan and program, the choice of appropriate training content, forms of work, application of appropriate training load as well as compliance with the periodization and competition calendar (Savić, Stojanović, Jorgić, Stojiljković, 2013).

The topic of this research (analysis of the age of alpine skiers winning medals at the most important world competitions) defines the content and marks the framework of set tasks and goals whose statistical processing should clarify the set problem and subject of research. This problem has only been partially investigated in similar works and other sports. There is not so many similar research in skiing, which is the reason why the authors decided to investigate this problem. That is why this research gives new material, new comments and conclusions, ie. emphasizes the essentials in the context of practical application.

Authors David J. Hancock, Ashley L. Adler \& Jean Côté (2013) in their research consider the relative ageeffect (RAE) of athletes through different social contexts and highlight the importance of the theoretical model (RAE). In the paper "Variations in the relative effects of age in certain sports: skiing, skating and gymnastics", the authors Baker, Janning, Wong, Cobley \& Schorer (2014) also point to the term relative age effect (RAE) which we will not use in its original form in this research, since in the competition season we did not take into account the exact date of birth of the competitors, but only the year of birth. Regarding to this, we will use the notion of relative age of competitors (RA).

Domestic authors Kasum and Radović (2006) in a similar study analyzed the age structure of Greco-Roman style wrestlers, participants in the Athens Olympics 2004, and concluded that their average age was 27 years, the average age of the top ten wrestlers was 27.3 years while the average age of the medal winners was 27 years and the average age of the winners was 24.2 years. The authors concluded that the ideal time to achieve the best results is between the ages of 23 and 31 . This research is methodologically set not to deal with causal relationships, 
but only to analyze, discuss and conclude on the occasion of the presented arithmetic means of the relative years of age of alpine skiers medals winners at the world's most important competitions.

The ancient value of sports is less pronounced in modern era. Some current needs of professional sports have emerged from a new values. The development of scientific thought in modern society in the field of sports is mostly based on achieving victory, and top results. The values of this research were observed with the interdisciplinary approach because of its necessity. Such and similar analyzes can enable us to do some new research on the value of elite sport and its further development.

\section{SUBJECT, PROBLEM AND OBJECTIVE OF THE WORK}

The subject of the paper would refer directly to the analysis of the average age of alpine skiers medal winners in alpine disciplines in the last completed Olympic cycle 2015-2018. year, with reference to the disciplines, season and type of competition.

The problem is implied in the increase and decrease of average age in certain alpine disciplines and competition seasons.

Based on the target sample, ie. of alpine skiers medals winners in certain alpine disciplines, a specific research objective has been formed. The aim of the paper would be to compare the differences in the relative years of age by seasons and disciplines and to contribute to everyday practice, ie. recommendations to trainers to create their long-term goals and training plans in accordance with the results of this research. The contribution was to achieve the ultimate goal practical application in practice, ie. the ability to generate new theories and hypotheses.

\section{WORK METHODOLOGY}

In this qualitative study, the research took into account the target sample (Stojiljković, Bratić, Sporiš, 2020), ie. the sample was selected on the basis of a special characteristic interesting for this research - medal winners at the world's most important competitions. The target sample of this research was derived from a representative sample of alpine skiers and can serve to generalize the results of the alpine skier population. The results from the tables and graphs are descriptively treated and interpreted. A descriptive method was used, as well as the method of analysis and critique. The conclusions were established on the same basis. 
Univariate statistics were used to calculate the average age, which calculates statistical parameters for one variable, a measure of the central tendency, ie. the arithmetic mean (average value) of the relative age of alpine skiers. In the discussion and analysis of the obtained results, the comparison with the median was abandoned due to the great coincidence of the obtained results, especially when it comes to the tendencies of the average age by seasons and disciplines.

\section{ANALYSIS AND DISCUSSION}

Table 1. Mean age of medal winners

\begin{tabular}{|c|c|c|c|c|c|c|c|c|c|c|c|c|c|c|c|}
\hline \multirow{2}{*}{$-\stackrel{\frac{\pi}{9}}{\varrho}$} & \multirow{2}{*}{ WC } & \multicolumn{3}{|c|}{ MEAN (age) } & \multirow[b]{2}{*}{ Total } & \multirow{2}{*}{ WSC } & \multicolumn{3}{|c|}{ Age } & \multirow[b]{2}{*}{ MEAN } & \multirow{2}{*}{ WOG } & \multicolumn{3}{|c|}{ Age } & \multirow[b]{2}{*}{ MEAN } \\
\hline & & 1. & 2. & 3. & & & 1. & 2. & 3. & & & 1. & 2. & 3. & \\
\hline \multirow{4}{*}{$\frac{\mathscr{\Omega}}{\stackrel{\varrho}{\varrho}}$} & $2014 / 15$ & 26,9 & 28,8 & 28,3 & 28 & $2014 / 15$ & 31 & 28 & 31 & 30 & $2014 / 15$ & & & & \\
\hline & $2015 / 16$ & 24,9 & 26,9 & 28,2 & 26,67 & $2015 / 16$ & & & & & $2015 / 16$ & & & & \\
\hline & $2016 / 17$ & 26,1 & 30,4 & 30 & 28,83 & $2016 / 17$ & 28 & 25 & 33 & 28,67 & $2016 / 17$ & & & & \\
\hline & $2017 / 18$ & 28,33 & 24,56 & 27,44 & 26,78 & $2017 / 18$ & & & & & $2017 / 18$ & 36 & 26 & 25 & 28,67 \\
\hline \multirow{4}{*}{ 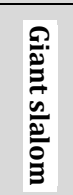 } & $2014 / 15$ & 25,25 & 27,38 & 28,63 & 27,08 & $2014 / 15$ & 31 & 26 & 24 & 27 & $2014 / 15$ & & & & \\
\hline & $2015 / 16$ & 27,33 & 27,33 & 27,11 & 27,26 & $2015 / 16$ & & & & & $2015 / 16$ & & & & \\
\hline & $2016 / 17$ & 26,38 & 28,13 & 28 & 27,5 & $2016 / 17$ & 28 & 26 & 30 & 28 & $2016 / 17$ & & & & \\
\hline & $2017 / 18$ & 28,29 & 24 & 28 & 26,76 & $2017 / 18$ & & & & & $2017 / 18$ & 29 & 24 & 27 & 26,67 \\
\hline \multirow{4}{*}{ 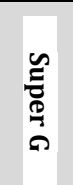 } & $2014 / 15$ & 28,43 & 26,86 & 28,86 & 28,05 & $2014 / 15$ & 35 & 25 & 31 & 30,67 & $2014 / 15$ & & & & \\
\hline & $2015 / 16$ & 29,88 & 27,63 & 28,75 & 28,75 & $2015 / 16$ & & & & & $2015 / 16$ & & & & \\
\hline & $2016 / 17$ & 32 & 32 & 30,67 & 31,56 & $2016 / 17$ & 36 & 32 & 33 & 33,67 & $2016 / 17$ & & & & \\
\hline & $2017 / 18$ & 30,5 & 31 & 31,83 & 31,11 & $2017 / 18$ & & & & & $2017 / 18$ & 28 & 31 & 33 & 30,67 \\
\hline \multirow{4}{*}{ 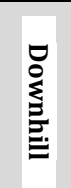 } & $2014 / 15$ & 30,6 & 28,8 & 29,8 & 29,73 & $2014 / 15$ & 31 & 27 & 28 & 28,67 & $2014 / 15$ & & & & \\
\hline & $2015 / 16$ & 30,55 & 30,64 & 31,82 & 31 & $2015 / 16$ & & & & & $2015 / 16$ & & & & \\
\hline & $2016 / 17$ & 30,5 & 33 & 32,5 & 31,75 & $2016 / 17$ & 30 & 36 & 28 & 31,33 & $2016 / 17$ & & & & \\
\hline & $2017 / 18$ & 29,89 & 30,67 & 31,33 & 30,63 & $2017 / 18$ & & & & & $2017 / 18$ & 36 & 33 & 31 & 33,33 \\
\hline \multirow{4}{*}{ AC } & $2014 / 15$ & 26,5 & 26 & 35,5 & 29,33 & $2014 / 15$ & 26 & 30 & 31 & 29 & $2014 / 15$ & & & & \\
\hline & $2015 / 16$ & 27 & 29,33 & 32 & 29,44 & $2015 / 16$ & & & & & $2015 / 16$ & & & & \\
\hline & $2016 / 17$ & 23,5 & 27 & 25 & 25,17 & $2016 / 17$ & 24 & 28 & 29 & 27 & $2016 / 17$ & & & & \\
\hline & $2017 / 18$ & 27,5 & 30,5 & 34 & 30,67 & $2017 / 18$ & & & & & $2017 / 18$ & 29 & 27 & 29 & 28,33 \\
\hline
\end{tabular}

Legend: MEAN. - Average values; WC - FIS Alpine Ski World Cup; WSC - FIS Alpine Ski World Championship; WOG - Winter Olympic Games.

Table no. 1 clearly and concisely gives the basic results of the arithmetic mean value of the relative age of the medal winners by seasons, disciplines and competition categories (WC, WSC, WOG), ie. provides good opportunities for 
comparisons, discussion and reasoning. With a general retrospection, we can see that the obtained values oscillate according to the competition seasons, which indicates the justification of this research. The lowest value expressed in the table is 25.17 years of age of competitors in the Alpine Combined (AC) in the 2016/17 season. year (as a consequence of the surprising victory of the young Swiss Hintermann in Wengen), and the highest is 33.67 in Super $g$ (SG) in the same season 2016/17.

Due to the frequency of victories and/or winning medals of individuals, e.g. Marcel Hirscher (AUT), Henrik Kristoffersen (NOR), Alexis Pinturault (FRA) in some disciplines, the relative age of competitors on the podium in one season did not change significantly, but the numbers grew through the seasons due to the aging of these competitors.

The oscillations by seasons (especially in slalom) and the decline in the relative average age in the 2015/16 seasons are a consequence of the dominance of younger competitor (Kristoffersen) at that time and podiums for Schwartz (AUT) and Matt (AUT).

Charts no. 4 and no. 5 show the tendency of growth of the average relative age of medal winners for the first three years of the Olympic cycle in the disciplines downhill (DH), super giant slalom (SG) and giant slalom (GS), while in slalom (SL) and alpine combined (AC) this is not the case.

In addition to chronological age, other important elements of athlete development planning include socialization, motivation and mental training (Ropret, 2019). This study was based only on relative age. The presented graphs $(1,2,3,4,5$ and 6$)$ give us a clear insight into the average age of the skiers who won medals at the mentioned competitions. It is recognized that the winners in the World Cup (WC) are younger than the second and third place competitors, while in the World Championships (WSC) and the Winter Olympic Games (WOG) the situation is different. Only in the Alpine Combined (AC) event younger competitors were winners. 
Graph 1. Mean age of medal winners in different events at FIS Alpine Ski World Cup

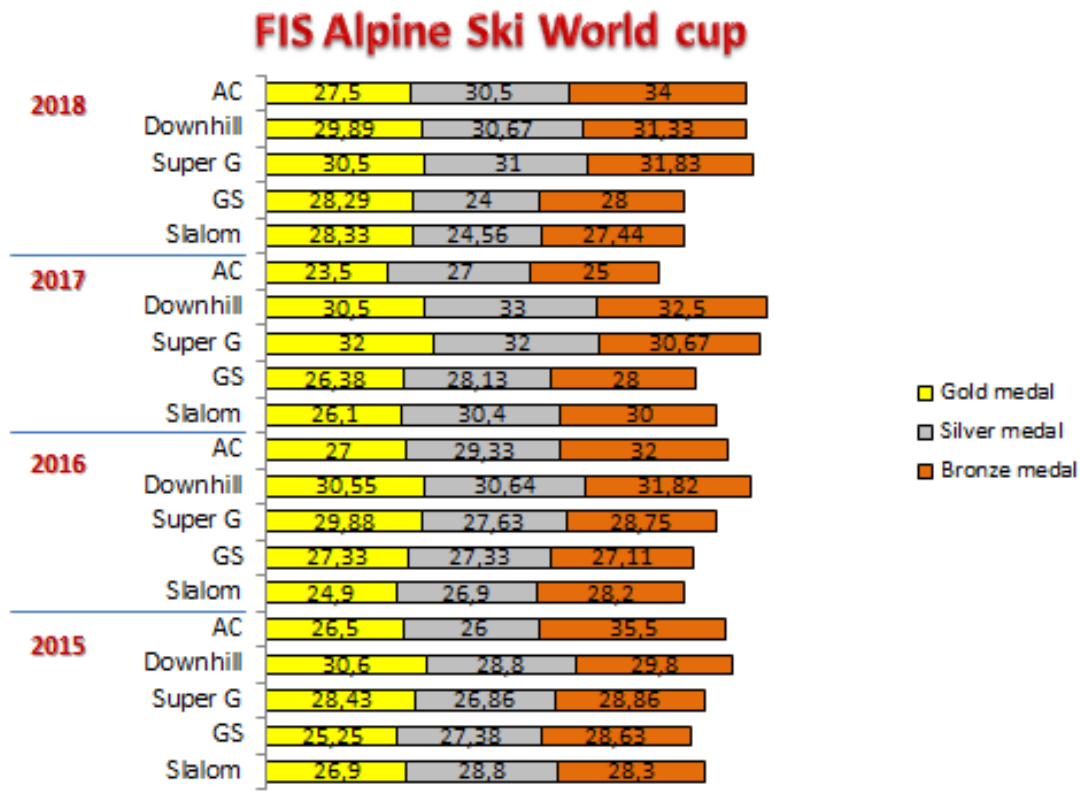

Graph 2. Age of medal winners in different events at FIS Alpine World Championship

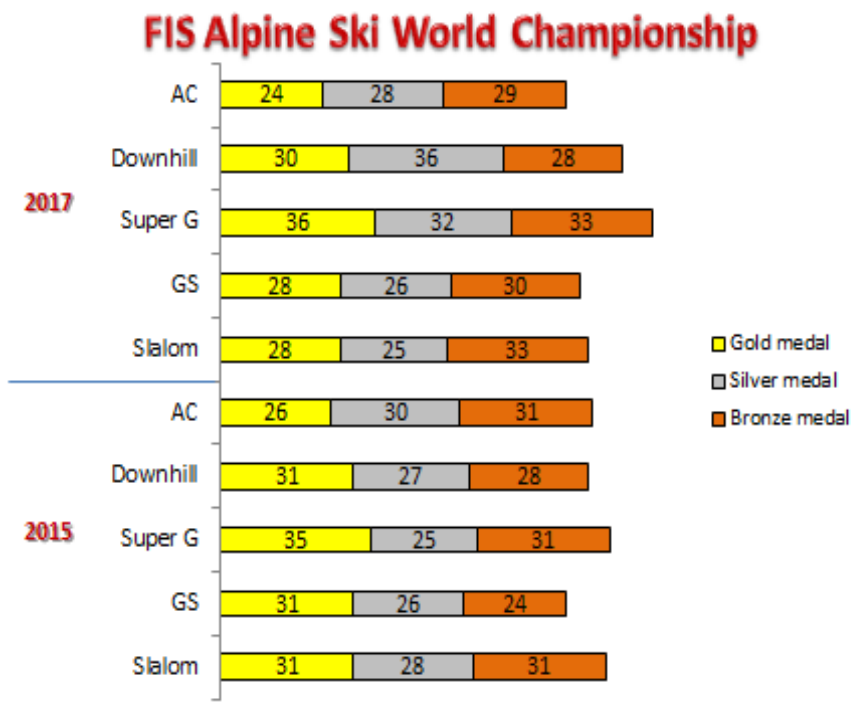


Graph 3. Age of medal winners in different events at Winter Olympic Games

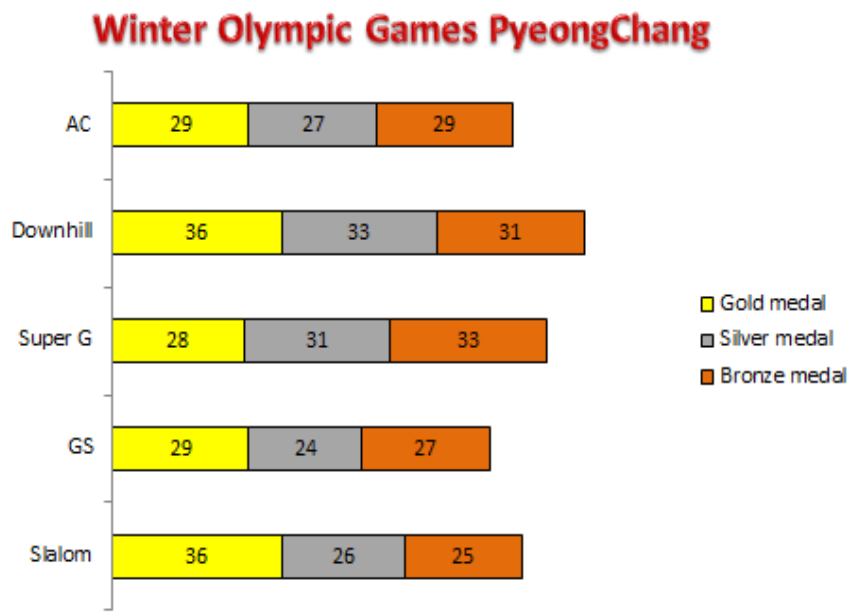

Graph 4. Mean age of medal winners at FIS Alpine World Cup

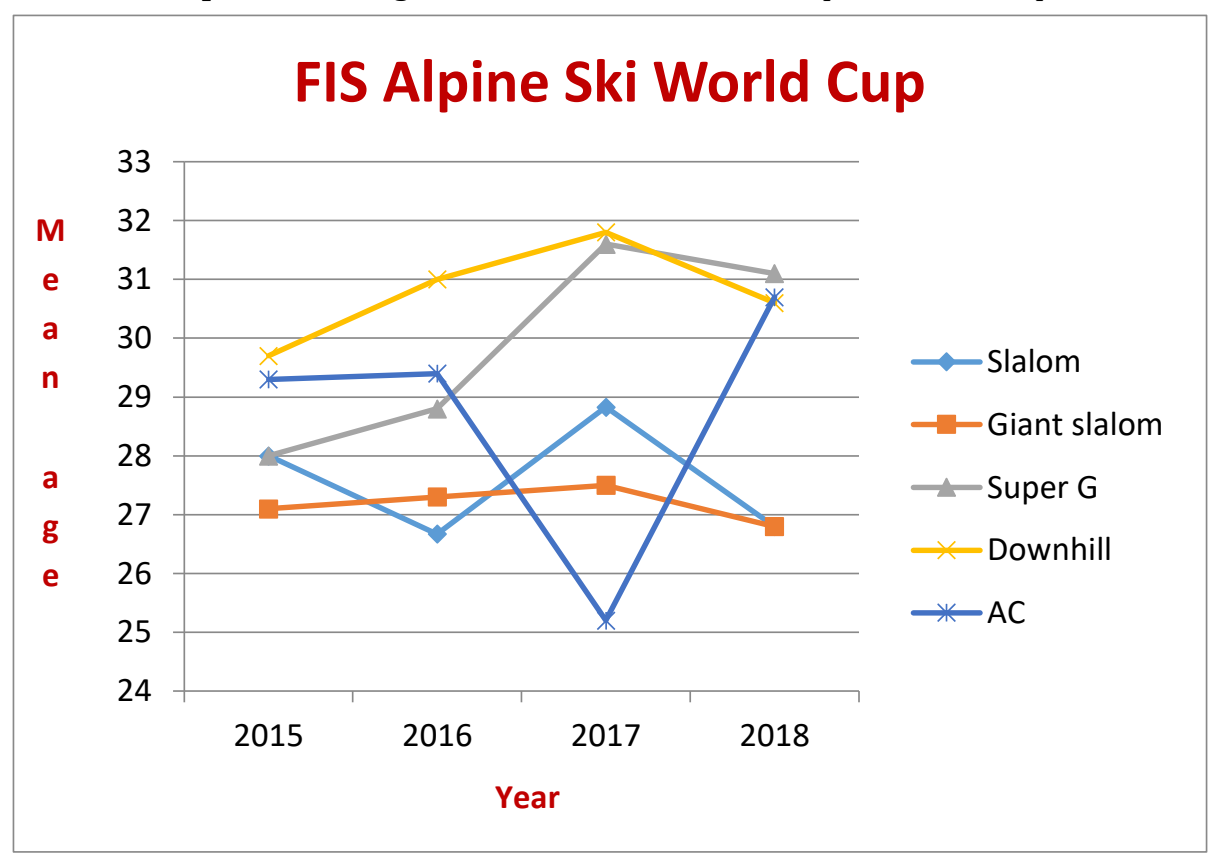


Graph 5. Mean age of medal winners at FIS Alpine Ski World Championship

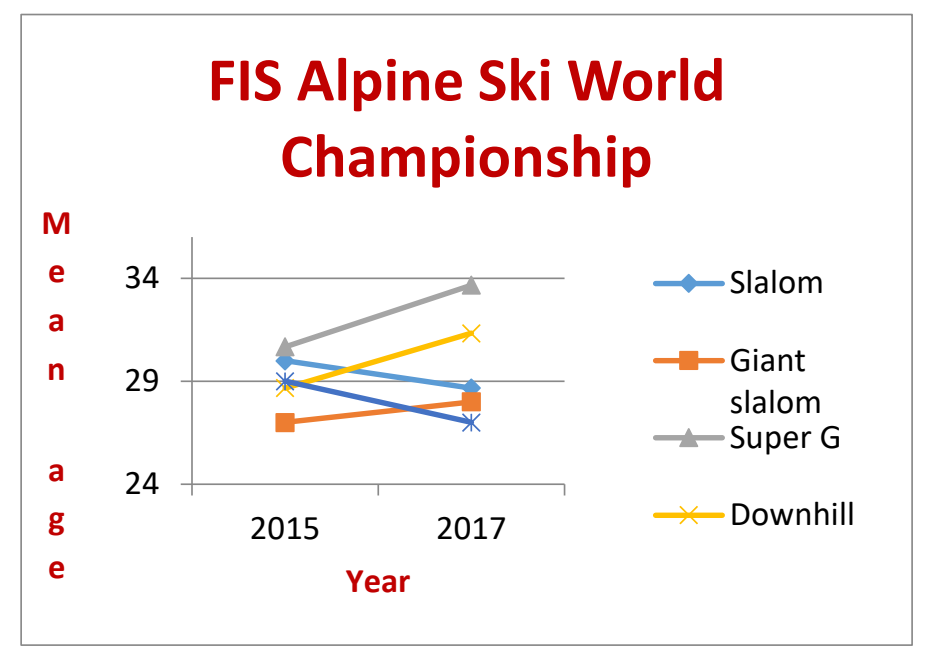

Graph 6. Mean age of medal winner at Winter Olympic Games

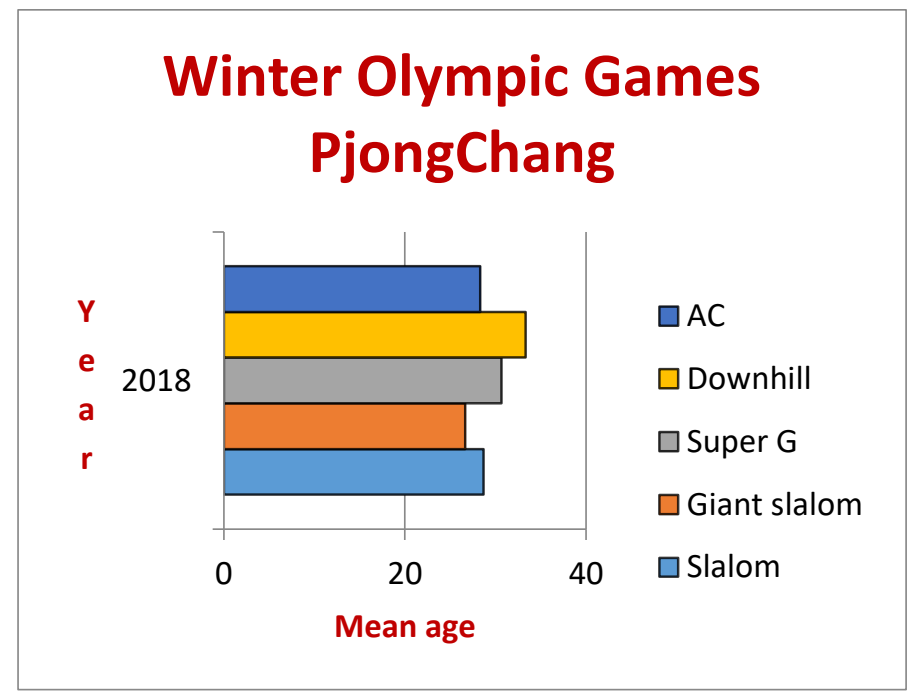




\section{CONCLUSION}

Today, sport as a modern social phenomenon also solves certain social problems, but it also sets new norms. The twenty-first century symbolizes the beginning of a new sports era. Thus, sports principles today exist on the principles of professionalism and sports profit. Throughout history, sport has played a significant role in every society, so it has attracted a lot of attention. Throughout history, sport developed with a constant tendency to increase top results and win as many medals as possible. With certainty we can assume that behind today's top results is the sports industry in which a lot is invested and from which a lot is earned (Savić, Randjelović, Stojanović, Stanković, \& Šiljak, 2017). New technological challenges of the ski industry are related to lighter and faster torsion-resistant skis - "calm" in turns of different radii, but also to a combination of shorter and longer ski in the beginner training (Stojanović, Savić, Stjepović, \& Lilić, 2017).

The obtained results of this research should be taken into consideration with caution, given the fact that several factors decide the winner, affect the result respectively. In most cases, the result depends on subjective factors, individual technical and tactical abilities and psychophysical readiness of athletes. However, the result in skiing often depends on other unpredictable factors: equipment quality, equipment technical malfunction, poor track inspection, ski dropouts, falls and disqualifications of opponents, "riding" gates, start errors, dropout - loss of pole, sudden adverse weather conditions, high starting number etc.

The characteristic of modern skiing is that the career of the competitors has significantly extended. In the seasons 1967-1971 the average age of medal winners (WOG, WSC, WC) was 20.7 (women) 24.3 years (men) while in the seasons 2009-2013 the age was 25.8 and 28.7 years, which is shift - career extension for about 5 years.

The results of this research showed the tendency to extend the sports career for a few more years regarding fast events, and maintenance or a slight decline for technical events. From this perspective, it is recommended for coaches who plan the training process over a longer period of time (long-term development planning for youth or several Olympic cycles for older athletes) to project the peak form in terms of achieving top results in major competitions in accordance with the results of this and other similar research.

The modern value framework of this research is reflected through several spheres: social, result, media, marketing, health, philosophical, and personal. Individually, each of them promotes and modernizes skiing and the accompanying sports industry (material sphere). It is difficult to determine which of them is the most important. That is why it is necessary to observe them as an indivisible whole, and interdisciplinary because only then they show their full contribution. 
The paper considers sports results, which must be observed with caution, in the context of other values.

\section{REFERENCE}

1. Baker, Joseph, Christina Janning, Harmonie Wong, Stephen Cobley, and Joerg Schorer. 2014. "Variations in relative age effects in individual sports: Skiing, figure skating and gymnastics." European Journal of Sport Science 14 (sup1):S183-S190.

2. Ekeland, Eilin, Frode Heian, Kåre Birger Hagen, Jo M Abbott, and Lena Nordheim. 2004. "Exercise to improve self-esteem in children and young people." Cochrane database of systematic reviews (1).

3. Hancock, David J, Ashley L Adler, and Jean Côté. 2013. "A proposed theoretical model to explain relative age effects in sport." European journal of sport science 13 (6):630-637.

4. Kasum, G., and M. Radović. 2007. "Povezanost starosne strukture rvača i vrhunskih rezultata u rvanju grčko - rimskim stilom (Relationship between the age structure of wrestlers and top results in Greco - Roman style wrestling)." Glasnik Antropološkog Društva Jugoslavije 42:75-84.

5. Lau, Patrick WC, CW Yu, Antoinette Lee, and Rita YT Sung. 2004. "The physiological and psychological effects of resistance training on Chinese obese adolescents." Journal of Exercise Science and Fitness 2 (2):115-120.

6. Matković, B., S. Ferenčak, and M. Žvan. 2004. Skijajmo zajedno (Let's ski together). Zagreb: Faculty of Kinesiology, Zagreb.

7. Ropert, R. 2019. Višegodišnji program razvoja sportiste u alpskom skijanju (A multi-year program for the development of athletes in alpine skiing). Belgrade: Ski Association of Serbia

8. Savić, Z., and V. Stjepović. 2019. Priručnik za instruktore skijanja (Handbook for ski instructors). Belgrade: Ski Association of Serbia.

9. Savić, Zvezdan, Nebojša Ranđelović, Nikola Stojanović, Veroljub Stanković, and Violeta Šiljak. 2018. "The sports industry and achieving top sports results." Facta Universitatis, Series: Physical Education and Sport 15 (3):513-522.

10. Savić, Zvezdan, Toplica Stojanović, Nenad Stojiljković, and Bojan Jorgić. 2013. "Differences in the space of motor skills between younger male and female skiers." Facta universitatis-series: Physical Education and Sport 11 (2):147-156.

11. Stojanović, N., Z. Savić, V. Stjepović, and Lj. Lilić. 2017. "From telemark to carving." Sportlogia 13 (1):66-73.

12. Stojiljković, N., M. Bratić, and G. Sporiš. 2020. Naučno istraživaćki rad u sportu i fizičkom vaspitanju (Scientific research in sports and physical education). Niš: Faculty of Sport and Physical Education, University of Niš.

13. Živanović, N., Z. Savić, A. Milojević, and D. Milutinović. 2003. Alpsko skijanje tehnika, metodika i psihofizička priprema (Alpine skiing - technique, methodology and psychophysical preparation). Niš: Panaoptikum. 


\section{АНАЛИЗА СТАРОСТИ АЛПСКИХ СКИЈАША ОСВАЈАЧА МЕДАЉА У ОЛИМПИЈСКОМ ЦИКЛУСУ 2015-2018. ГОДИНА}

САЖЕТАК

Мотивација, знатижеља, као и ангажовање и рад у скијању навели су ауторе да приближе читаоцима и стручној јавности резултате једне овакве анализе, подкрепљене статистичким резултатима значајним за праксу. У раду су анализиране релативне године старости професионалних алпских скијаша освајача медаља на Светским куповима, Светским првенствима и Олимпијским играма у олимпијском циклусу 2015-2018. година, тј. од такмичарске 2014/15. па до 2017/18. Анализиране су следеће алпске дисциплине: слалом SL, влелеслалом GS, суперџи SG, спуст D и алпска комбинација AC. Предмет рада сагледан је кроз узрочно последичне везе просечних година старости такмичара на подијуму по сезонама и дисциплинама у којима су наступали. Примењена је основна дескриптивна статистика која нам је пружила аритметичке средине и медијане који су указали на просечно већу старост такмичара у брзим дисциплинама (SG i D) у односу на техничке дисциплине (SL, GS, SG), као и чињеницу да се продужила скијашка каријера такмичара, тј. старост такмичара у сезони 2017/18. је већа од сезоне 2014/15. године.

Кључне речи: скијаши, године старости, такмичења, анализа, циклус.

\section{АНАЛИЗ ВОЗРАСТНОЙ КАТЕГОРИИ ПРИЗЕРОВ ОЛИМПИЙСКОГО ЦИКЛА 2015-2018 ГОДОВ В ГОРНОЛЫЖНОМ СПОРТЕ}

\footnotetext{
АННОТАЦИЯ

Мотивация, любопытство, а также вовлеченность в занятия горнолыжным спортом побудили авторов представить читателям и профессиональной общественности результаты такого анализа, который может быть важен для практики. В статье анализируется средний возраст профессиональных горнолыжников, завоевавших медали в соревнованиях на Кубок мира, чемпионатах мира и Олимпийских играх в олимпийском цикле 2015-2018, то есть с 2014/2015 по 2017/2018 гг. Были проведен анализ следующих видов горнолыжного спорта: Слалом (SL), Слалом-гигант (GS), Супер G (SG), Скоростной спуск (DH) и Горное двоеборье (AC). Целью данной работы было рассмотрение причинно-следственных связей среднего возраста спортсменов на пьедестале почета по сезонам и видам соревнований, в которых они выступали. Были применены основные описательные статистики, которые на основе рассчитанных средних арифметических и медиан указали на более
} 
высокий средний возраст спортсменов в скоростных видах (SG и DH) по сравнению с техническими (SL, GS), а также на то, что горнолыжная карьера спортсменов была увеличена. Возраст спортсменов в сезоне 2017/2018 выше, чем в сезоне 2014/2015 для скоростных видов (DH, SG, AC) и 2016/2017, чем 2014/2015 для технических (SL, GS).

Ключевые слова: лыжники, возраст, соревнования, анализ, олимпийский цикл.

Reccived on 18.04.2021.

Accepted on 19.05.2021. 